\title{
IDENTIFIKASI TOMATO INFECTIOUS CHLOROSIS VIRUS PENYEBAB PENYAKIT KLOROSIS PADA TANAMAN TOMAT DI CIPANAS JAWA BARAT MELALUI PERUNUTAN NUKLEOTIDA GEN PROTEIN SELUBUNG UTAMA
}

\author{
Fitrianingrum Kurniawati, Gede Suastika, \& Giyanto \\ Departemen Proteksi Tanaman Fakultas Pertanian Institut Pertanian Bogor \\ Jl. Meranti, Kampus IPB Dramaga, Bogor 16680 \\ E-mail: fitrianingrumk@gmail.com
}

\begin{abstract}
Identification of tomato infectious chlorosis virus, the causal agent of chlorosis disease on tomato in Cipanas West Java by sequencing of main coat protein gene nucleotide. Tomato infectious chlorosis virus (TICV) causes chlorosis on tomato. Tomatoes infected by this virus shows interveinal yellowing, necrotic, bronzing, brittleness, and declining in productivity. This study aims to identify the causal agent of chlorotic disease on tomato by sequencing the coat protein gene. The methods involve collecting infected plants, total RNA extraction, cDNA synthesis, DNA amplification, visualization of the results of reverse transcription polymerase chain reaction (PCR), and phylogenetic analysis using BLAST, clustal w, Bioedit v 7.0.5.3, MEGA v 6:06. RT-PCR using spesific primers (CP-FTICV Bam and TICV R-Hind) amplified a DNA band of $792 \mathrm{bp}$, which has been successfully sequenced and identified as TICV. Nucleotide sequences homology analysis showed that TICV Indonesia_TWJ isolate Cipanas is the same strain as TICV from other countries (99.4-100\%), such as Spain, Greece, USA, France, and Italy.
\end{abstract}

Key words: chlorosis disease, coat protein gene, reverse transcription polymerase chain reaction, sequencing, TICV

\section{ABSTRAK}

Identifikasi Tomato infectious chlorosis virus penyebab penyakit klorosis pada tanaman tomat di Cipanas Jawa Barat melalui perunutan nukleotida gen protein selubung utama. Tomato infectious chlorosis virus (TICV) merupakan penyebab penyakit klorosis pada tanaman tomat. Tomat yang terserang penyakit ini menunjukkan gejala klorosis pada bagian antara tulang daun, nekrotik, bronzing, daun mudah rapuh, dan produksi buah menurun. Penelitian ini bertujuan untuk mengidentifikasi penyebab penyakit klorosis pada tanaman tomat melalui perunutan nukleotida gen protein selubung. Metode penelitian ini meliputi pengumpulan tanaman sakit, ekstraksi RNA total tanaman, sintesis cDNA, amplifikasi DNA, visualisasi hasil reverse transcription polymerase chain reaction (RT-PCR), analisis perunutan nukleotida dan filogenetika menggunakan program BLAST, Clustal W, Bioedit Sequence Alignment Editor v 7.0.5.3, MEGA v 6.06. Berdasarkan hasil RT-PCR menggunakan pasangan primer spesifik (TICV CP-F Bam dan TICV R-Hind) diperoleh pita DNA berukuran $792 \mathrm{pb}$, telah berhasil dirunut berdasarkan runutan basa nukleotida dan diidentifikasi sebagai TICV. Analisis homologi runutan nukleotida menunjukkan bahwa TICV TWJ asal Cipanas merupakan strain virus yang sama dengan TICV dari negara lain (99.4-100\%) seperti Spanyol, Yunani, USA, Perancis, dan Italia.

Kata kunci: gen coat protein, klorosis, perunutan nukleotida, TICV, reverse transcription polymerase chain reaction

\section{PENDAHULUAN}

Tanaman tomat merupakan salah satu tanaman hortikultura yang mempunyai banyak manfaat. Salah satu hambatan dalam budi daya tomat adalah serangan virus tanaman. Banyak jenis virus tanaman yang telah dilaporkan menyerang tanaman tomat. Tomato mosaic virus (ToMV) (Xue et al., 1998), Tomato chlorosis virus (ToCV) (Segev et al., 2004), Tomato yellow leaf curl virus (TYLCV) (Köklü et al., 2006), Tomato leaf curl virus (TLCV) (Reddy et al., 2005), dan Tomato spotted wilt virus (TSWV) (Hu et al., 2011) merupakan virus yang telah dilaporkan menyerang tanaman tomat di beberapa negara. Beberapa tahun terakhir ini di berbagai negara telah dilaporkan adanya virus baru yang menginfeksi tanaman tomat. Tanaman tomat yang terinfeksi virus ini menunjukkan gejala klorosis, sehingga penyakitnya disebut dengan penyakit klorosis. Penyakit klorosis ini disebabkan oleh Tomato infectious chlorosis virus (TICV) (Dalmon et al., 2005; Tsai et al., 2004). Penyakit ini telah ditemukan di beberapa sentra produksi tomat di Indonesia, seperti Garut, Cianjur, Bogor, 
Magelang, Rinjani, dan Yogyakarta (Hartono \& Wijonarko, 2007; Fitriasari, 2010; Suastika et al., 2010; Sa'adah, 2013).

Gejala serangan TICV pada tanaman tomat ditunjukkan oleh daun-daun menguning (Duffus et al., 1996), klorosis pada bagian antara tulang daun. Gejala klorosis yang sangat parah akan menyebabkan daun mengalami nekrotik (kematian jaringan) dan menjadi rapuh, serta ukuran buah menjadi lebih kecil, mudah gugur dan proses pemasakan terganggu sehingga hasil panen menurun (Wisler et al., 1998a; Wisler et al., 1998b).

TICV ditularkan dari satu tanaman ke tanaman lainnya oleh serangga vektor Trialeurodes vaporariorum (Hemiptera: Aleyrodidae) yang dikenal dengan nama kutu kebul. Penularan dapat terjadi secara cepat ke seluruh areal pertanaman karena serangga vektor bersifat aktif. TICV ditularkan oleh serangga vektor secara semipersisten (Duffus et al., 1996; Wintermantel, 2004).

Teknik deteksi TICV berbasis molekuler melalui reverse transcription polymerase chain reaction (RTPCR) telah dilakukan oleh para peneliti. Teknik deteksi ini dilakukan dengan menggunakan pasangan primer yang berbeda-beda tergantung dari bagian mana yang akan diamplifikasi. Hartono \& Wijonarko (2007) serta Jacquemond et al. (2009) telah melakukan deteksi TICV dengan teknik RT-PCR menggunakan pasangan primer heat shock protein (HSP-70h), Fitriasari (2010) menggunakan pasangan primer yang telah disisipi dengan runutan enzim restriksi Bam HI dan HindIII (TICV-CP F Bam dan TICV-CP R Hind), Orillio \& Navas-Castillo (2009), Andriani (2011), dan Nurulita \& Suastika (2013) menggunakan pasangan primer TICVCF dan TICV-CR. Deteksi dengan RT-PCR dapat dilakukan dengan cepat dan hasilnya akurat.

Teknik deteksi berbasis molekuler selain RT-PCR adalah dengan perunutan DNA (sequencing). Perunutan DNA adalah proses penentuan urutan nukleotida pada suatu fragmen DNA. Tujuan dari proses ini adalah untuk menentukan identitas maupun fungsi fragmen suatu DNA dengan membandingkannya dengan fragmen DNA lain yang telah diketahui. Nurulita \& Suastika (2013) telah melakukan perunutan nukleotida TICV pada gen protein selubung minor $(\mathrm{CPm})$. Perbedaan $\mathrm{CPm}$ dan $\mathrm{CP}$ terletak pada fungsinya. $\mathrm{CPm}$ berperan dalam penularan dengan reseptornya, $\mathrm{CP}$ utama berperan dalam perakitan virus. Perunutan nukleotida gen protein selubung utama (CP) belum pernah dilakukan sehingga penelitian ini bertujuan untuk mengidentifikasi TICV penyebab penyakit klorosis pada tanaman tomat melalui perunutan nukleotida gen protein selubung utama (CP).

\section{METODE PENELITIAN}

Tempat dan Waktu. Penelitian ini dilaksanakan di Laboratorium Virologi Tumbuhan, Fakultas Pertanian Institut Pertanian Bogor dan Laboratorium Biokimia Balai Besar Bioteknologi dan Sumber Daya Genetik Pertanian (BB-BIOGEN), pada bulan November 2011 sampai dengan Februari 2012.

Pengumpulan Tanaman Sakit. Pengambilan sampel tanaman bergejala klorosis dilakukan secara purposif (purposive sampling). Pengambilan dan pengumpulan sampel dilakukan di desa Pacet, Kecamatan Cipanas, Kabupaten Cianjur, Jawa Barat. Daun tanaman yang terinfeksi TICV diamati dan difoto gejalanya, kemudian diambil untuk diidentifikasi dengan menggunakan reverse transcription polymerase chain reaction (RT-PCR).

Ekstraksi RNA Total. Ekstraksi RNA total dilakukan dengan menggunakan Qiagen RNAeasy Plant Mini Kit dan dikerjakan sesuai dengan protokol yang diberikan (Qiagen, 2001).

Sintesis complementary (c) DNA. RNA hasil ekstraksi disintesis menjadi cDNA dengan menggunakan teknik Reverse Transcription Polymerase Chain Reaction (RT-PCR). Proses RT-PCR dilakukan menggunakan kit komersial Access RT-PCR System (Promega, US). Hasil ekstraksi RNA berupa RNA total selanjutnya dilakukan sintesis complementary cDNA melalui proses Reverse Transcription (RT) atau transkipsi balik yang digunakan untuk mengubah RNA menjadi cDNA. Tabung mikro diisi dengan $10 \mu 1$ reaksi $\mathrm{RT}$ yang terdiri atas $1 \mathrm{x} \mathrm{ddH}_{2} \mathrm{O}$ $3,7 \mu 1,10 x$ bufer RT $2 \mu 1,10 \mathrm{mM}$ dNTP $0,5 \mu 1,50 \mathrm{mM}$ dTT $0,35 \mu \mathrm{l}, 10 \mu \mathrm{M}$ random heksamer $0,75 \mu \mathrm{l}$, MMuLV Rev 0,35 $\mu$ l, Ribolock $0,35 \mu$ l, dan RNA $2 \mu$ l. Komponenkomponen tersebut digunakan untuk satu kali reaksi RT. Reaksi RT dilakukan dalam sebuah Automated Thermal cycler (Gene Amp PCR System 9700; PE Applied Biosystem, US) yang diprogram untuk satu siklus pada suhu $25{ }^{\circ} \mathrm{C}$ selama 5 menit, $42{ }^{\circ} \mathrm{C}$ selama 60 menit, dan $70{ }^{\circ} \mathrm{C}$ selama 15 menit. Siapan cDNA hasil RT digunakan sebagai templat dalam reaksi PCR.

Amplifikasi DNA. Reaksi PCR dengan total volume $25 \mu 1$ digunakan untuk memperbanyak pita cDNA yang telah terbentuk dari proses RT. Komposisi bahan yang digunakan dalam reaksi PCR terdiri atas 2x Go tag green 
master mix PCR 12,5 $\mu 1,10 \mu \mathrm{M}$ Primer spesifik TICVCP F-Bam no ATG (5'-AATTAAGGATCCGAAAACT TATCTGGTAATGCAAAC-3') $1 \mu 1$ dan TICV-CP RHind (5'-AATTAAAAGCTTTTAGCATGGGTGTT TCATATCAGCC-3') (Fitriasari, 2010) $1 \mu \mathrm{l}, 1 \mathrm{x}$ ddH2O $8,5 \mu \mathrm{l}$, dan $2 \mu \mathrm{l}$ cDNA hasil RT. Proses ini didahului dengan denaturasi awal pada $94{ }^{\circ} \mathrm{C}$ selama 4 menit, dilanjutkan dengan 30 siklus yang terdiri dari denaturasi pada $94{ }^{\circ} \mathrm{C}$ selama 1 menit, penempelan primer (annealing) pada $55^{\circ} \mathrm{C}$ selama 1 menit, dan pemanjangan (Extension) pada $72{ }^{\circ} \mathrm{C}$ selama 2 menit. Kontrol positif TICV yang digunakan adalah sampel tanaman tomat yang terinfeksi TICV hasil penelitian Fitriasari (2010), kontrol negatif menggunakan template tanaman tomat sehat, sampel TICV Indonesia_TWJ berasal dari tanaman tomat yang bergejala interveinal yellowing.

Visualisasi Hasil RT-PCR. Hasil amplifikasi DNA yang didapat dari proses PCR selanjutnya dilakukan visualisasi dengan elekroforesis gel agarose $1 \%$ dalam bufer elektroforesis Tris-borat EDTA 0,5x (40 mM Tris, $20 \mathrm{mM}$ sodium asetat, dan $1 \mathrm{mM}$ EDTA, $\mathrm{pH} 7,0$ ) dengan pewarnaan ethidium bromide $(0,5 \mu \mathrm{g} / 10 \mathrm{ml})$. Visualisasi pita DNA dilakukan dengan meletakkan gel agarose pada $U V$ translluminator. Dokumentasi pita DNA dilakukan menggunakan kamera digital.

Analisis Perunutan Nukleotida dan Filogenetik. Sebanyak $50 \mu 1$ hasil PCR dikirim ke PT. Genetika Science Indonesia untuk disekuensing. Elektroforegram yang didapatkan dianalisis menggunakan program sequence scanner v 1.0 (Applied Biosystem, USA). Hasil perunutan nukleotida yang diperoleh kemudian dikonfirmasi ke GenBank dengan program Basic Local Alignment Search Tool (BLAST) yang tersedia pada
National Center for Biotechnology Information (NCBI, 2014). Runutan nukleotida yang telah dikonfirmasi kemudian disejajarkan dengan menggunakan penyejajaran berganda ClustalW pada program Bioedit Sequence Alignment Editor v 7.0.5.3 (Hall, 1999). Pohon filogenetika dikonstruksi menggunakan perangkat lunak Molecular Evolutionary Genetic Analysis Software (MEGA) v 6.06 dengan metode UPGMA menggunakan boostrap 1000 kali ulangan. Rujukan runutan nukleotida isolat TICV dari negara lain diperoleh dari GenBank.

\section{HASIL DAN PEMBAHASAN}

Penyakit Klorosis pada Tanaman Tomat. Survei yang dilakukan di Desa Pacet, Kecamatan Cipanas, Kabupaten Cianjur, Provinsi Jawa Barat berhasil menemukan tanaman tomat yang memperlihatkan gejala klorosis. Penyakit ini ditandai dengan perubahan warna kuning pada jaringan diantara tulang daun (interveinal yellowing), yang dimulai dari daun-daun tua di bagian bawah kemudian berkembang ke bagian pucuk (Gambar 1A); kadang-kadang terjadi perubahan warna pada bagian daun menjadi merah keunguan (bronzing) (Gambar 1B); dan pada gejala lanjut beberapa bagian daun klorotik mengalami nekrotik (Gambar 1C). Gejala semacam ini bersesuaian dengan gejala yang diinduksi oleh TICV menurut peneliti terdahulu (Duffus et al., 1996; Li et al., 1998; Wintermantel \& Wisler, 2006; Wisler et al., 1998a).

Deteksi dengan RT-PCR. Amplifikasi menggunakan primer spesifik TICV-CP F-Bam no ATG dan TICVCP R-Hind berhasil mendapatkan pita DNA dengan ukuran sekitar $792 \mathrm{pb}$ (Gambar 2), hal ini sesuai dengan hasil penelitian Fitriasari (2010). Produk RT-PCR TICV
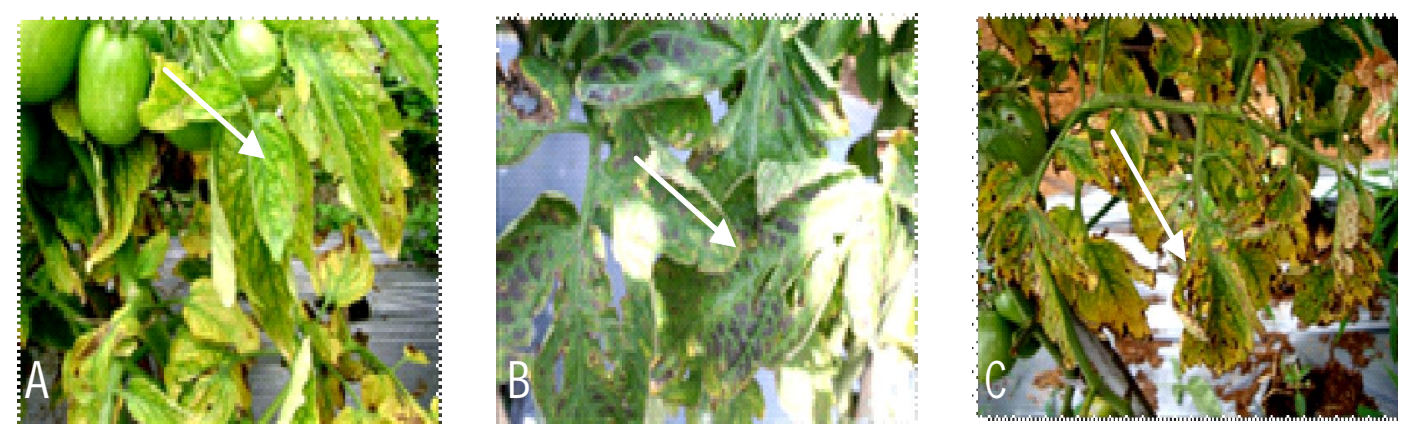

Gambar 1. Gejala penyakit klorosis pada tanaman tomat yang ditemukan di lapangan; (A) Interveinal yellowing; (B) Terjadi perubahan warna pada bagian daun menjadi merah keunguan (bronzing) dan (C) daun mengalami nekrotik 




Gambar 2. Hasil amplifikasi sampel DNA CP-TICV dengan metode RT-PCR. Lajur 1: marker $1 \mathrm{~kb}$ (Fermentas, US), Lajur 2: kontrol negatif (tanaman tomat sehat), Lajur 3: kontrol positif (TICV penelitian Fitriasari, 2010), Lajur 4: sampel tanaman tomat yang terinfeksi TICV dari lapangan yang menunjukkan gejala interveinal yellowing

berhasil dirunut, dan hasil runutan menunjukkan kualitas yang baik dan tidak ada kesalahan dalam perunutan berdasarkan analisis kesejajaran.

\section{Analisis Perunutan Nukleotida dan Filogenetik.}

Menurut Barton (1998) analisis tingkat homologi runutan nukleotida merupakan cara yang sahih untuk mengidentifikasi suatu spesies virus. Homologi urutan nukleotida virus penyebab klorosis pada tanaman tomat dapat dilihat pada Tabel 1.
Homologi TICV Indonesia_TWJ dengan TICV dari negara lain berkisar antara 99,4-100\%. Menurut Fauquet et al. (2005) jika suatu spesies virus mempunyai persamaan runutan nukleotida pada bagian gen protein selubung lebih dari $90 \%$ maka virus-virus tersebut merupakan suatu spesies virus yang sama. Hal ini menunjukkan bahwa spesies TICV TWJ yang berasal dari Cipanas, Jawa Barat merupakan spesies TICV yang sama dengan TICV yang berasal dari negara Spanyol, Yunani, US A, Italia, dan Perancis.

Tabel 1. Homologi runutan nukleotida virus penyebab klorosis pada tanaman tomat di Cipanas, Jawa Barat (TICV Indonesia_TWJ) dengan TICV yang telah dilaporkan oleh beberapa negara lain

\begin{tabular}{|c|c|c|c|c|c|c|c|c|}
\hline \multirow{2}{*}{ No } & \multirow{2}{*}{ Nama Isolat } & \multirow{2}{*}{ No Aksesi } & \multicolumn{6}{|c|}{ Homologi (\%) } \\
\hline & & & 1 & 2 & 3 & 4 & 5 & 6 \\
\hline 1 & TICV Indonesia_TWJ & & $\mathrm{D}$ & & & & & \\
\hline 2 & TICV Spanyol_SP5131 & FJ542305 & 100 & ID & & & & \\
\hline 3 & TICV Yunani_TI-Th173 & HG380072 & 99,7 & 99,7 & ID & & & \\
\hline 4 & TICV USA_CA4 & FJ542306 & 99,7 & 99,7 & 100 & ID & & \\
\hline 5 & TICV Perancis_Fr & EU625351 & 99,6 & 99,6 & 99,8 & 99,8 & ID & \\
\hline 6 & TICV USA_OC & FJ815441 & 99,4 & 99,4 & 99,7 & 99,7 & 99,6 & ID \\
\hline
\end{tabular}

TICV Indonesia_TWJ (1) : Isolat TICV Cipanas, Jawa Barat, Indonesia

TICV Spanyol_SP1531 (2) : Isolat TICV Spanyol (Orilio \& Navas-Castillo, 2009)

TICV Yunani_TI-Th173 (3) : Isolat TICV Yunani (Orfanidou et al., 2014)

TICV USA_CA4 (4) : : Isolat Amerika Utara dan Eropa (Orilio \& Navas-Castillo, 2009)

TICV Perancis_Fr (5) : Isolat Perancis (Jacquemond et al., 2009)

TICV USA_OC (6) : Isolat Orange County, California, Amerika Serikat (Wintermantel et al., 2009) 
Panjang gen protein selubung TICV adalah sekitar 760 pb (Hartono et al., 2003). Panjang sebagian gen protein selubung TICV yang berhasil dirunut dan disejajarkan berkisar 792 pb (Gambar 3). Runutan nukleotida sebagian gen protein selubung isolat TICV Indonesia_TWJ yang berasal dari Cipanas, Jawa Barat setelah disejajarkan dengan isolat-isolat TICV dari negara lain terletak antara nukleotida ke- 1 sampai 792 pada runutan nukleotida RNA2 genom TICV. Perbedaan runutan nukleotida antara isolat TICV Indonesia_TWJ (Cipanas-Jawa Barat) dengan isolat dari negara lain terjadi pada posisi nukleotida ke 29, 54, 212, 228, dan 525 (Gambar 3). Perunutan dan penyejajaran nukleotida ini dilakukan untuk memastikan bahwa runutan tersebut adalah runutan sebagian gen protein selubung TICV yang berada pada RNA 2 dari genom TICV (Orilio \& Navas-Castillo, 2009).

Analisis pohon filogenetika menunjukkan bahwa hubungan kekerabatan enam isolat TICV terbagi menjadi 2 kelompok (Gambar 4). Kelompok I terdiri dari isolat TICV asal Yunani, Amerika Utara dan Eropa (USA_CA4), Perancis (Fr). Indonesia, Spanyol, dan Amerika Serikat Orange County (USA_OC). Hal ini menunjukkan bahwa isolat TICV asal Indonesia masih berkerabat dekat dengan isolat asal Spanyol, Amerika Serikat Orange County (USA_OC), Yunani, Perancis (Fr), Amerika Utara dan Eropa (USA_CA4).

A

Alignment: A:IPipietljurnal TICV\rawtext ticv 180615 new



TICV Ind ATGGAAAACT TATCTGGTAA TGCAAACTAT GATGAAACTA ACACCAGTCG TGTGAACTCT

TICV Spany ATGGAAAACT TATCTGGTAA TGCAAACTAT GATGAAACTA ACACCAGTCG TGTGAACTCT

TICV Yunan ATGGAAAACT TATCTGGTAA TGCAAACTAT GATGAAACTA ACACCAGTCG TGTAAACTCT

TICV USA_C ATGGAAAACT TATCTGGTAA TGCAAACTAT GATGAAACTA ACACCAGTCG TGTAAACTCT

TICV Peran ATGGAAAACT TATCTGGTAA TGCAAACTAT GATGAAACTA ACACCAGTCG TGTAAACTCT

TICV USA_O ATGGAAAACT TATCTGGTAA TGCAAACTTT GATGAAACTA ACACCAGTCG TGTAAACTCT

Clustal Co $\quad * * * * * * * * * * * * * * * * * * * * * * * * * * * * * * * * * * * * * * * * * * * * * * * * * * * * * * * * * * * * * * *$

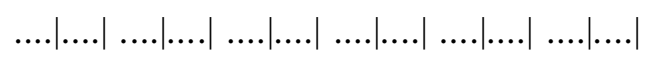

$$
\begin{aligned}
& \begin{array}{llllll}
65 & 75 & 85 & 95 & 105 & 115
\end{array}
\end{aligned}
$$

TICV Ind GATGGAATTG GAAGTCACAT GGAGCATGAT GATGATGACA GGTCAGTCAA CGGACCTCCA

TICV Spany GATGGAATTG GAAGTCACAT GGAGCATGAT GATGATGACA GGTCAGTCAA CGGACCTCCA

TICV Yunan GATGGAATTG GAAGTCACAT GGAGCATGAT GATGATGACA GGTCAGTCAA CGGACCTCCA

TICV USA_C GATGGAATTG GAAGTCACAT GGAGCATGAT GATGATGACA GGTCAGTCAA CGGACCTCCA

TICV Peran GATGgAATTG GAAGTCACAT GGAGCATGAT GATGATGACA GGTCAGTCAA CGGACCTCCA

TICV USA_O GATGGAATTG GAAGTCACAT GGAGCATGAT GATGATGACA GGTCAGTCAA CGGACCTCCA

Clustal Co $\quad * * * * * * * * * * * * * * * * * * * * * * * * * * * * * * * * * * * * * * * * * * * * * * * * * * * * * * * * * * * * * * * *$ 


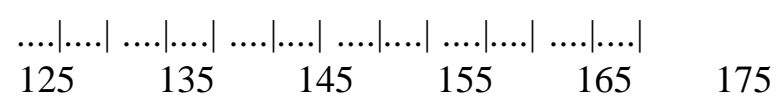

TICV Ind AGTGATGAGA TAAACAATCA TACTACGAGA TCTGTTCATG GTAGAGATCA CACGTCAGGT

TICV Spany AGTGATGAGA TAAACAATCA TACTACGAGA TCTGTTCATG GTAGAGATCA CACGTCAGGT

TICV Yunan AGTGATGAGA TAAACAATCA TACTACGAGA TCTGTTCATG GTAGAGATCA CACGTCAGGT

TICV USA_C AGTGATGAGA TAAACAATCA TACTACGAGA TCTGTTCATG GTAGAGATCA CACGTCAGGT

TICV Peran AgTGATGAGA TAAACAATCA TACTACGAGA TCTGTTCATG GTAGAGATCA CACGTCAGGT

TICV USA_O AGTGATGAGA TAAACAATCA TACTACGAGA TCTGTTCATG GTAGAGATCA CACGTCAGGT

Clustal Co $* * * * * * * * * * * * * * * * * * * * * * * * * * * * * * * * * * * * * * * * * * * * * * * * * * * * * * * * * * * * * * * * * *$

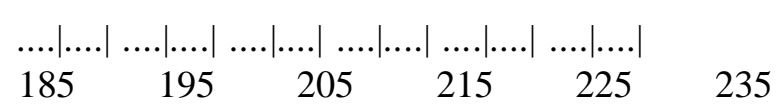

TICV Ind AATATAGGAG ATTACTCAAA AGCTGACTTG AATAGAATTA TGGTCAAAGT CAGTAGACCG

TICV Spany AATATAGGAG ATTACTCAAA AGCTGACTTG AATAGAATTA TGGTCAAAGT CAGTAGACCG

TICV Yunan AATATAGGAG ATtACTCAAA AGCTGACTTG AATAGAATTA TGGTCAAGGT CAGTAGACCG

TICV USA_C AATATAGGAG ATTACTCAAA AGCTGACTTG AATAGAATTA TGGTCAAGGT CAGTAGACCG

TICV Peran AATATAGgAg ATtACTCAAA AGCTGACTTG AATAGAATTA TGGTCAAGGT CAGTAGACCG

TICV USA_O AATATAGGAG ATTACTCAAA AGCTGACTTG AGTAGAATTA TGGTCAAGGT CAGTAGACCG

Clustal Co $\quad * * * * * * * * * * * * * * * * * * * * * * * * * * * * * * * * * * * * * * * * * * * * * * * * * * * * * * * * * * * * * * * *$

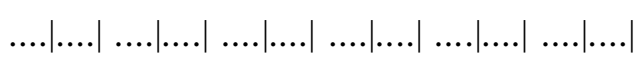

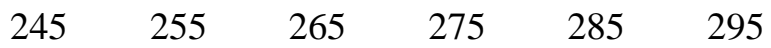

TICV Ind GATGCTATGA GTGAATCCGATAGTAACTTG TATAAAGAGG TGATTGTTGAATATCTGAAA TICV Spany GATGCTATGA GTGAATCCGA TAGTAACTTG TATAAAGAGG TGATTGTTGA ATATCTGAAA

TICV Yunan GATGCTATGA GTGAATCCGA TAGTAACTTG TATAAAGAGg TGATTGTTGA ATATCTGAAA

TICV USA_C GATGCTATGA GTGAATCCGA TAGTAACTTG TATAAAGAGG TGATTGTTGA ATATCTGAAA

TICV Peran GATGCTATGA GTGAATCCGA TAgtAACTTG TATAAAgAgG TGATtgttgA ATATCTGAAA

TICV USA_O GATGCTATGA GTGAATCCGA TAGTAACTTG TATAAAGAGG TGATTGTTGA ATATCTGAAA

Clustal Co $\quad * * * * * * * * * * * * * * * * * * * * * * * * * * * * * * * * * * * * * * * * * * * * * * * * * * * * * * * * * * * * * * *$

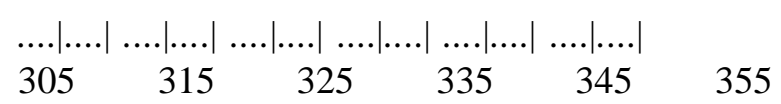

TICV Ind AACAATTGTACTGGAGGTGC GGAACCGGAT AAAGTTTTAG TGGTTGCATT TTTTGTTGCA 
TICV spany AACAATTGTA CTGGAGGTGC GGAACCGGAT AAAGTTTTAG TGGTTGCATT TTTTGTTGCA

TICV Yunan AACAATTGTA CTGGAGGTGC GGAACCGGAT AAAGTTtTAG TGgTtgCATT TTTTGTTGCA TICV USA_C AACAATTGTA CTGGAGGTGC GGAACCGGAT AAAGTTTTAG TGGTTGCATT TTTTGTTGCA

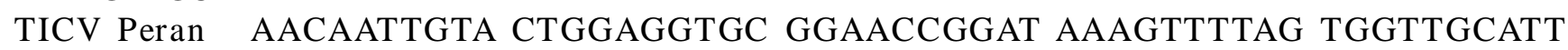
TTTTGTTGCA TICV USA_O AACAATTGTA CTGGAGGTGC GGAACCGGAT AAAGTTTTAG TGGTTGCATT TTTTGTTGCA

Clustal Co $\quad * * * * * * * * * * * * * * * * * * * * * * * * * * * * * * * * * * * * * * * * * * * * * * * * * * * * * * * * * * * * * * * *$

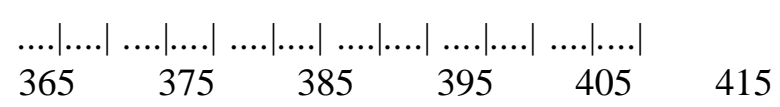

TICV Ind CTATGTCAGT ATGCTCTCAACTCTGGCACT TCGGTTAAAG CAATAAGTGACAGGACTGTG TICV Spany CTATGTCAGT ATGCTCTCAA CTCTGGCACT TCGGTTAAAG CAATAAGTGA CAGGACTGTG

TICV Yunan CTATGTCAGT ATGCTCTCAA CTCTGGCACT TCGGTTAAAG CAATAAGTGA CAGGACTGTG

TICV USA_C CTATGTCAGT ATGCTCTCAA CTCTGGCACT TCGGTTAAAG CAATAAGTGA CAGGACTGTG

TICV Peran CTATGTCAGT ATGCTCTCAA CTCTGGCACT TCGGTTAAAG CAATAAGTGA CAGGACTGTG

TICV USA_O CTATGTCAGT ATGCTCTCAA CTCTGGCACT TCGGTTAAAG CAATAAGTGA CAGGACTGTG

Clustal Co $\quad * * * * * * * * * * * * * * * * * * * * * * * * * * * * * * * * * * * * * * * * * * * * * * * * * * * * * * * * * * * * * * * * *$

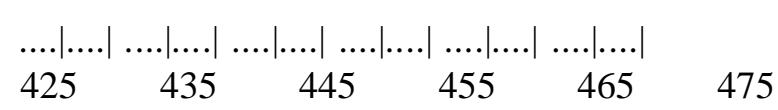

TICV Ind GATTTGAGTT TTGGGTATGACAATCAAAAATATACAGTTAAAGCGGGACATTTTTTATCA TICV Spany GATTTGAGTT TTGGGTATGA CAATCAAAAA TATACAGTTA AAGCGGGACA TTTTTTATCA

TICV Yunan GATtTGAGTT TTGgGTATGA CAATCAAAAA TATACAGTTA AAGCGGGACA TTTTTTATCA

TICV USA_C GATTTGAGTT TTGGgTATGA CAATCAAAAA TATACAGTTA AAGCGGGACA TTTTTTATCA

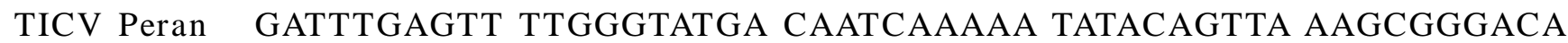
TTTTTTATCA

TICV USA_O GATTTGAGTT TTGGGTATGA CAATCAAAAA TATACAGTTA AAGCGGGACA TTTTTTATCA

Clustal Co $\quad * * * * * * * * * * * * * * * * * * * * * * * * * * * * * * * * * * * * * * * * * * * * * * * * * * * * * * * * * * * * * * * *$

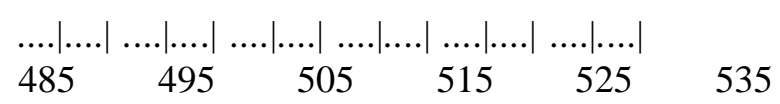

TICV Ind TATGCTCAAT CTAGAACGTC AGGTCACCCAAACGCTCTAA GGAGGTTCAT GCGATCTAGT TICV Spany TATGCTCAAT CTAGAACGTC AGGTCACCCA AACGCTCTAA GGAGGTTCAT GCGATCTAGT

TICV Yunan TATGCTCAAT CTAGAACGTC AGGTCACCCA AACGCTCTAA GGAGGTTCAT GCGATCTAGT

TICV USA_C TATGCTCAAT CTAGAACGTC AGGTCACCCA AACGCTCTAA GGAGGTTCAT GCGATCTAGT 
TICV Peran TATGCTCAAT CTAGAACGTC AGGTCACCCA AACGCTCTAA GGAGATTCAT GCGATCTAGT

TICV USA_O TATGCTCAAT CTAGAACGTC AGGTCACCCA AACGCTCTAA GGAGGTTCAT GCGATCTAGT

Clustal Co $\quad * * * * * * * * * * * * * * * * * * * * * * * * * * * * * * * * * * * * * * * * * * * * * * * * * * * * * * * * * * * *$

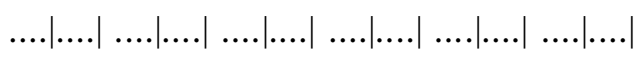

$$
\begin{aligned}
& \begin{array}{llllll}
545 & 555 & 565 & 575 & 585 & 595
\end{array}
\end{aligned}
$$

TICV Ind CTGGAAACAG TTAAACAACT ACAAGATGTT GGGCTGATAT ATTCTAATGG AGTCGTGGCC TICV Spany CTGGAAACAG TTAAACAACT ACAAGATGTT GGGCTGATAT ATTCTAATGG AGTCGTGGCC

TICV Yunan CTGGAAACAG TTAAACAACT ACAAGATGTT GGGCTGATAT ATtCTAATGG AGTCGTGGCC

TICV USA_C CTGGAAACAG TTAAACAACT ACAAGATGTT GGGCTGATAT ATTCTAATGG AGTCGTGGCC

TICV Peran CTGGAAACAg TTAAACAACT ACAAGATGTt GgGCTGATAT ATtCTAATGG AGTCGTGGCC

TICV USA_O CTGGAAACAG TTAAACAACT ACAAGATGTT GGGCTGATAT ATTCTAATGG AGTCGTGGCC

Clustal Co c $_{*} * * * * * * * * * * * * * * * * * * * * * * * * * * * * * * * * * * * * * * * * * * * * * * * * * * * * * * * * * * * * * *$

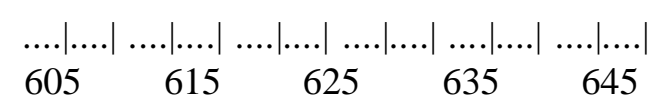

TICV Ind GCGAAACATG GGgTtgTGAA AGAATtCAGA AACAGCTATG CAGACTTtGA CACTGGTCAT

TICV Spany GCGAAACATG GGGTTGTGAA AGAATTCAGA AACAGCTATG CAGACTTTGA CACTGGTCAT

TICV Yunan GCGAAACATG GGGTTGTGAA AGAATTCAGA AACAGCTATG CAGACTTTGA CACTGGTCAT

TICV USA_C GCGAAACATG GGGTTGTGAA AGAATTCAGA AACAGCTATG CAGACTTTGA CACTGGTCAT

TICV Peran GCGAAACATG GgGtTgtgaA AgAatTCAGA AACAGCTATG CAGACTTtga CACTGGTCAT

TICV USA_O GCGAAACATG GGGTTGTGAA AGAATTCAGA AACAGCTATG CAGACTTTGA CACTGGTCAT

Clustal Co $\quad * * * * * * * * * * * * * * * * * * * * * * * * * * * * * * * * * * * * * * * * * * * * * * * * * * * * * * * * * * * * * * * * *$

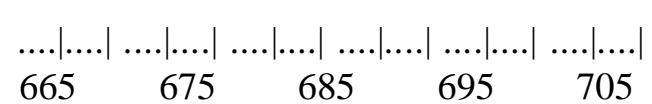

TICV Ind CTAGACAGAATGTCTAACGACGATCTGGCT GCGTTGATGT TAGCTAAATG TCATGCATTG TICV Spany CTAGACAGAA TGTCTAACGA CGATCTGGCT GCGTTGATGT TAGCTAAATG TCATGCATTG

TICV Yunan CTAGACAGAA TGTCTAACGA CGATCTGGCT GCGTTGATGT TAGCTAAATG TCATGCATTG

TICV USA_C CTAGACAGAA TGTCTAACGA CGATCTGGCT GCGTTGATGT TAGCTAAATG TCATGCATTG

TICV Peran CTAGACAgAA TGTCTAACGA CGATCTGGCT GCGTTGATGT TAgCtAAATG TCATGCATTG

TICV USA_O CTAGACAGAA TGTCTAACGA CGATCTGGCT GCGTTGATGT TAGCTAAATG TCATGCATTG

Clustal Co $\quad * * * * * * * * * * * * * * * * * * * * * * * * * * * * * * * * * * * * * * * * * * * * * * * * * * * * * * * * * * * *$ 


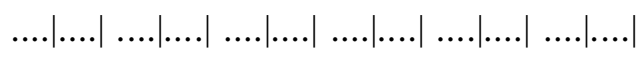

$$
\begin{aligned}
& \begin{array}{llllll}
725 & 735 & 745 & 755 & 765 & 775
\end{array}
\end{aligned}
$$

TICV Ind AAGAAATCCG AAGGTAATAG TAGAACTATATACAATACGG TGCAATTGGC TGATATGAAA TICV Spany AAGAAATCCG AAGGTAATAG TAGAACTATA TACAATACGG TGCAATTGGC TGATATGAAA

TICV Yunan AAGAAATCCG AAGGTAATAG TAGAACTATA TACAATACGG TGCAATTGGC TGATATGAAA

TICV USA_C AAGAAATCCG AAGGTAATAG TAGAACTATA TACAATACGG TGCAATTGGC TGATATGAAA

TICV Peran AAGAAATCCG AAGgTAATAG TAGAACTATA TACAATACGg TGCAATTGGC TGATATGAAA

TICV USA_O AAGAAATCCG AAGGTAATAG TAGAACTATA TACAATACGG TGCAATTGGC TGATATGAAA

Clustal Co $\quad * * * * * * * * * * * * * * * * * * * * * * * * * * * * * * * * * * * * * * * * * * * * * * * * * * * * * * * * * * * * * * * * * *$

$$
\begin{gathered}
\text {........ ... } \\
785
\end{gathered}
$$

TICV Ind CACCCATGCT AA

TICV Spany CACCCATGCT AA

TICV Yunan CACCCATGCT AA

TICV USA_C CACCCATGCT AA

TICV Peran CACCCATGCT AA

TICV USA_O CACCCATGCT AA

Clustal Co $* * * * * * * * * * * *$

Gambar 3. Runutan basa nukleotida gen protein selubung isolat TICV Indonesia_TWJ (Cipanas, Jawa Barat) dengan isolat TICV dari negara lain, huruf yang berwarna merah menunjukkan runutan nukleotida yang berbeda

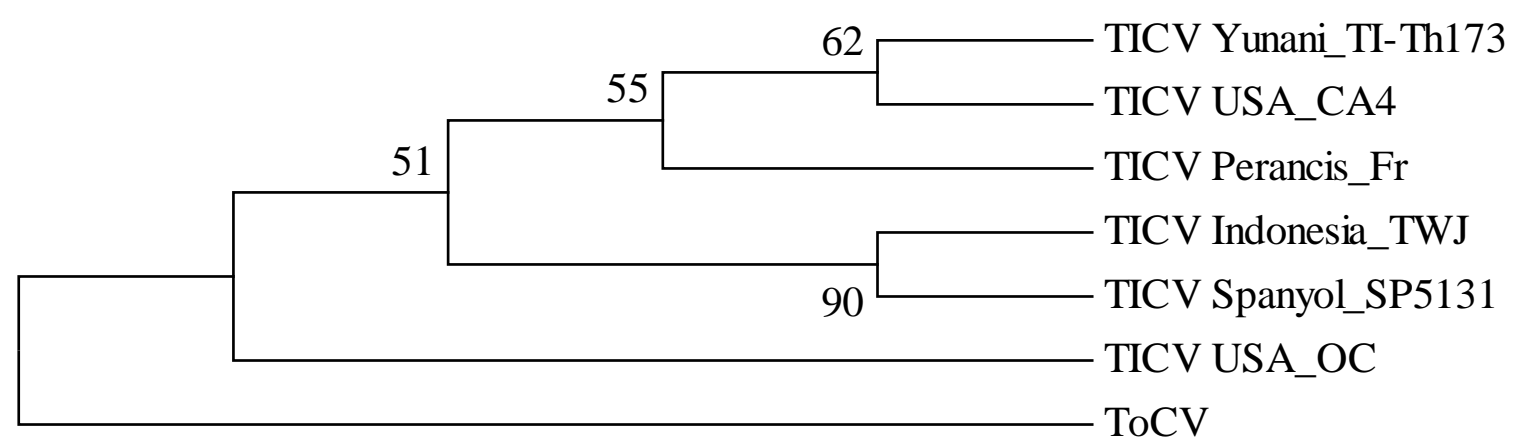

Gambar 4. Pohon filogenetika isolat-isolat TICV berdasarkan runutan nukleotida gen protein selubung menggunakan program MEGA v 6.06 dengan pendekatan UPGMA 


\section{SIMPULAN}

TICV isolat Cipanas berhasil dirunut nukleotidanya dan memiliki homologi sebesar 99,4100\% dibandingkan dengan isolat dari Negara Spanyol, Amerika Serikat Orange County (USA_OC), Yunani, Perancis (Fr), Amerika Utara dan Eropa (USA_CA4). TICV isolat Cipanas berada dalam satu kelompok dengan isolat Spanyol, Amerika Serikat Orange County (USA_OC), Yunani, Perancis (Fr), Amerika Utara dan Eropa (USA _CA4). Dengan demikian TICV isolat Cipanas merupakan spesies yang sama dengan TICV isolat Spanyol, Amerika Serikat Orange County (USA_OC), Yunani, Perancis (Fr), Amerika Utara dan Eropa (USA_CA4).

\section{DAFTAR PUSTAKA}

Andriani A. 2011. Deteksi diferensial Tomato chlorosis virus (ToCV) dan Tomato infectious chlorosis virus (TICV) dengan reverse transcription polymerase chain reaction (RT-PCR). Skripsi. Institut Pertanian Bogor. Bogor.

Barton GJ. 1998. Protein sequence alignment techniques. Acta Cryst. D54: 1139-1146.

Dalmon A, Bouyer S, Cailly M, Girard M, Lecoq H, Desbiez C, \& Jacquemond M. 2005. First report of Tomato chlorosis virus and Tomato infectious chlorosis virus in Tomato crops in France. Plant Dis. 89(11): 1243.

Duffus JE, Liu HY, \& Wisler GC. 1996. Tomato infectious chlorosis virus-a new clostero-like virus transmitted by Trialeurodes vaporariorum. Eur. J. Plant Pathol. 102(3): 219-226.

Fauquet CM, Mayo MA, Maniloff J, Desselberger U, \& Ball LA. 2005. Virus Taxonomy Eight Report of the International Committee on Taxonomy of Viruses. Virology Divison International Union of Microbiological Societies. San Diego.

Fitriasari ED. 2010. Keefektifan kutukebul dalam menularkan virus penyebab penyakit kuning pada tanaman tomat. Tesis. Institut Pertanian Bogor. Bogor.
Hall TA. 1999. Bioedit: a user-friendly biological sequence alignment editor and analysis program for windows 95/98/NT. Nucleic Acids Symp. Ser. 41: 95-98.

Hartono S, Natsuaki T, Sayama H, Atarashi Y, \& Okuda S. 2003. Yellowing disease of tomatoes caused by Tomato infectious chlorosis virus newly recognized in Japan. J. Gen. Plant Pathol. 69: 61-64.

Hartono S \& Wijonarko A. 2007. Biomolecular characterization of Tomato infectious chlorosis virus caused yellowing disease on tomato plants in Indonesia. J. Akta Agros Spec. 2: 139-146.

Hu ZZ, Feng ZK, Zhang ZJ, Liu YB, \& Tao XR. 2011. Complete genome sequence of a tomato spotted wilt virus isolate from China and comparison to other TSWV isolates of different geographic origin. Arch. Virol. 156(10): 1905-1908.

Jacquemond M, Verdin E, Dalmon A, Guilbaud L, \& Gognalons P. 2009. Serological and molecular detection of Tomato chlorosis virus and Tomato infectious chlorosis virus in tomato. Plant Pathol. 58(2): 210-220.

Köklü G, Rojas A, \& Kvarnheden A. 2006. Molecular identification and the complete nucleotide sequence of a Tomato yellow leaf curl virus isolate from Turkey. J. Plant Pathol. 88(1): 6166.

Li RH, Wisler GC, Liu HY, \& Duffus JE. 1998. Comparison of diagnostic techniques for detecting Tomato infectious chlorosis virus. Plant Dis. 82: 84-88.

[NCBI] National Center for Biotechnology Information. 2014. Basic Local Alignment Search Tool. http:/ /www.ncbi.nlm.nih.gov/BLAST. Diakses 15 Juli 2014.

Nurulita S \& Suastika G. 2013. Identifikasi Tomato infectious chlorosis virus dan Tomato chlorosis virus melalui reverse transcription polymerase chain reaction dan analisis sikuen nukleotida. J. Fitopatol. Indones. 9(4): 107115. doi: 10.14692/jfi.9.4.107. 
Orfanidou CG, Dimitriou C, Papayiannis LC, Maliogka VI, \& Katis NI. 2014. Epidemiology and genetic diversity of criniviruses associated with tomato yellows disease in Greece. Virus Res. 186: 120129.

Orílio AF \& Navas-Castillo J. 2009. The complete nucleotide sequence of the RNA2 of the Crinivirus Tomato infectious chlorosis virus: isolates from North America and Europe are essentially identical. Arch. Virol. 154(4): 683687.

Qiagen. 2001. RNeasy Mini Handbook. Ed-3. Qiagen Inc, Valencia.

Reddy RVC, Colvin J, Muniyappa V, \& Seal S. 2005. Diversity and distribution of begomoviruses infectiong tomato in India. Arch. Virol. 150(5): 845-867.

Sa'adah L. 2013. Uji serologi diferensial dan simultan Tomato chlorosis virus (ToCV) dan Tomato infectious chlorosis virus (TICV) pada tanaman tomat. Skripsi. Institut Pertanian Bogor. Bogor.

Segev L, Wintermantel WM, Polston JE, \& Lapidot M. 2004. First Report Tomato chlorosis virus in Israel. Plant Dis. 88(10): 1160.

Suastika G, Hartono S, Nishigawa H, \& Natsuaki T. 2010. Yellowing disease outbreaks in tomato in Indonesia associated with infection of Tomato chlorosis virus and Tomato infectious chlorosis virus[abstract]. ISSAAS International Congress 2010: Agricultural Adaptation in Response to Climate Change. Denpasar (ID). November 14-18, 2010.

Tsai WS, Shih SL, Green SK, \& Hanson P. 2004. First report of the occurrence of Tomato infectious chlorosis virus in Taiwan. Plant Dis. 88: 311.
Wintermantel WM. 2004. Emergence of green house whitefly (Trialeurodes vaporariorum) transmitted criniviruses as threats to vegetable and fruit production in North America. APS Net [jurnal on-line]. http://www.apsnet.org/online/ feature/whitefly/whitefly.pdf. Diakses 24 Maret 2009.

Wintermantel WM, Hladky LL, Gulati-Sakhuja A, Li R, Liu HY, \& Tzanetakis IE. 2009. The complete nucleotide sequence and genome organization of Tomato infectious chlorosis virus: a distinct crinivirus most closely related to lettuce infectious yellow virus. Arch. Virol. 154(8): 1335-1342.

Wintermantel WM \& Wisler GC. 2006. Vector specificity, host range, and genetic diversity of Tomato chlorosis virus. Plant Dis. 90(6): 814819.

Wisler GC, Duffus JE, Liu HY, \& Li RH. 1998a. Ecology and epidemiology of whitefly-transmitted closteroviruses. Plant Dis. 82(3): 270-280.

Wisler GC, Li RH, Liu HY, Lowry DS, \& Duffus JE. 1998b. Tomato chlorosis virus: a new whiteflytransmitted, phloem-limited, bipartite closterovirus of tomato. Phytopathology 88(5): 402-409.

Xue C, Zhou X, Liu Y, \& Li D. 1998. Cloning, sequence, analysis, and expression in E. coli of coat proteingene and 3' non-coding region of Tomato mosaic virus. Zhongguo Bing Du Xue 13: 150155. 